\title{
Effect of season on embryo production in Iraqi local black goat
}

\author{
A.F. Majeed ${ }^{1}$, I.H. Al-Timimi ${ }^{2}$ and M.N. Al-Saigh ${ }^{2}$ \\ ${ }^{1}$ Department of Surgery and Theriogenology, College of Veterinary Medicine, University of Fallujah, Fallujah, \\ ${ }^{2}$ Department of Surgery and Obstetrics, College of Veterinary Medicine, University of Baghdad, Baghdad, Iraq \\ 1email: af-majeed@yahoo.com
}

(Received April 19, 2018; Accepted July 8, 2018)

\begin{abstract}
The aim of this study was to investigate the effect of season on embryo production in Iraqi local black goat. 599 female genital system of Iraqi local black goat were collected from AL-Fallujah abattoir, AL-Anbar province during the period from July 2010 to the $1^{\text {st }}$ July 2011 . The oocytes were collected via aspiration and slicing. Only good and fair quality oocytes were selected for in vitro maturation. Fresh semen was used from two Bucks of proven fertility for fertilization. TALP, MEM, and TCM-199 culture media were used of in-vitro maturation (IVM) and in-vitro fertilization (IFV). It has been shown that high recovery and maturation rate $87.3 \%$ and $45.6 \%$ respectively were observed at breeding season as compared with recovery rate $72.5 \%$ and maturation rate $35.2 \%$ respectively in non-breeding season. There was a significant difference $(\mathrm{P}<0.05)$ in recovery rate and maturation rate between different season. It has been found that fertilization rate was $60.05 \%$ in breeding season. While it has $33.9 \%$ in non-breeding season. There was a significant difference in fertilization rate $(\mathrm{P}<0.05)$ between breeding and non-breeding season. Blastocyst obtained during breeding season was $56.41 \%$, while it was $43.24 \%$ in non-breeding season. There was a significant difference $(\mathrm{P}<0.05)$ between different season. It was concluded that there is an effect of season on oocyte recovery.
\end{abstract}

Keywords: Iraqi black goat, Season, Invitro, Embryo, Production Available online at http://www.vetmedmosul.com

$$
\begin{aligned}
& \text { تأثير الموسم على إنتاج الاجنة مختبريا في الماعز العراقي المحلي الأسود }
\end{aligned}
$$

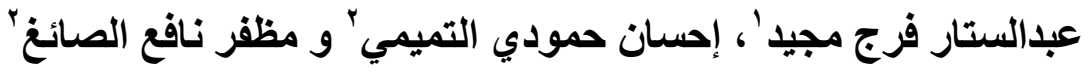

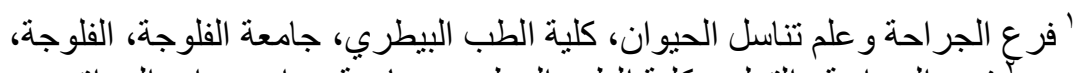

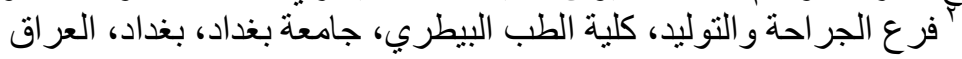

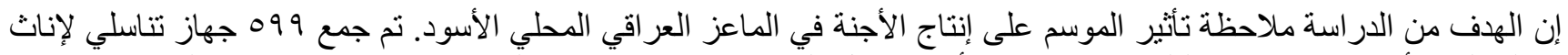

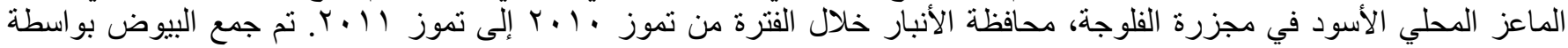

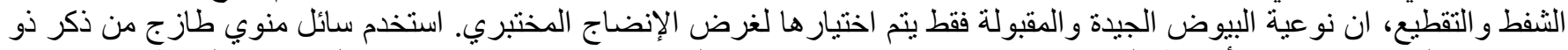

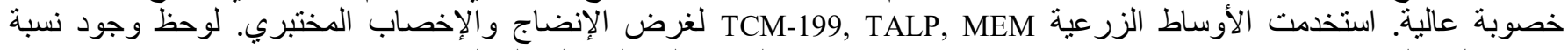

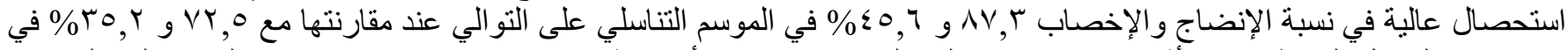

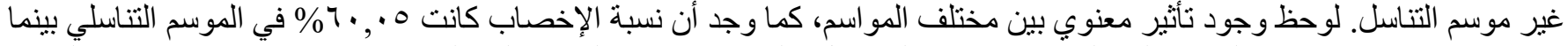

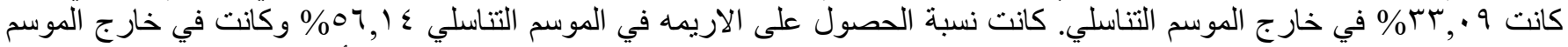

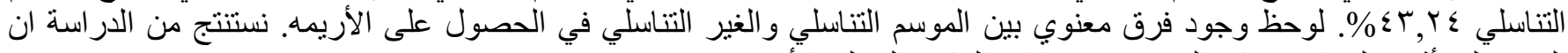
الموسم له نأثير على الإخصاب المختبري في إناث الماعز المحلي الأسود. 


\section{Introduction}

Goats are adapted to different environments and acts as a producer of meat, milk and hair. In vitro production of embryo is essential for worldwide production, it has been reported that the presence of a goat number of antral follicles on the ovaries of sheep is frequently observed even during the non-breeding season (1). Information about the ability of oocyte collected from antral follicles during the non-breeding season to undergo in vitro maturation (IVM) is taking (2). It has been found that there were no differences in efficiency of (IVM) of oocytes collected during the breeding and non-breeding season in sheep (3). It has been also claimed that the amount of estrogens produced by the ovarian follicles may differ between the season resulting in observed differences in occurrence of estrus (4). Estimation of estrogen content of sheep ovarian follicles during the breeding and non-breeding season could clarify this, alternatively, antral follicles that appear on ovaries during the non-breeding season may not grow to ovulatory size to produce sufficient estrogen (3). The ability of oocytes to undergo (IVM) as assistant by extrusion of the first polar body and development of meta phase I did not differ significantly between the season but was dependent upon the medium $(3,5)$, semen (6) and month (7). There is a little information about seasonality in black Iraqi goats. So, the study was designed to show the effect of season on in vitro embryo production in Iraqi local black goat.

\section{Material and methods}

\section{Ovarian processing}

599 female genital systems of Iraqi local black goat were collected from Al-Anbar province, AL-Fallujah abattoir. The reproductive status of the animals was not known. The samples were transported within one hour in a normal saline at $33-35^{\circ} \mathrm{C}$ in cool box to the Theriogenology lab, Department of Surgery and Theriogenology, College of Veterinary Medicine, University of Fallujah, Fallujah. The breeding season in Iraqi goats occurs during May, June, July, August and September months (8). In the lab the ovaries were removed with a sterile scissor and freed from the surrounding tissue and over lying bursa. Each ovary was subjected to three washing in normal saline and two washing in collecting media (TCM-199, MEM and TALP) (9). The follicles were counted and their diameters were taking with an automatic vernier. The oocytes were collected by one of the following methods in the hood cabinet; aspiration and slicing.

Aspiration: two to eight $\mathrm{mm}$ size follicles were aspirated using an 18-gauge needle attached with a sterile $3 \mathrm{ml}$ disposable syringe containing $2 \mathrm{ml}$ of collected medium (10). The media with harvested oocytes were transferred to one well out of 24 wells dish.
Slicing: ovaries were placed in a sterile petri dish containing $10 \mathrm{ml}$ of collecting media, held with the forceps and the ovarian surface was incised with scalpel blade. The petri dish was examined under dissecting microscope and the oocytes transferred with a sterile pasteur pipette to one well out 24 wells petri dish. Then in both techniques the petri dish was kept undisturbed for five minutes allowing the oocytes to settle down. The wells of petri dish were examined under inverted microscope and then the total numbers of collected oocytes were counted (9).

\section{Grading of oocytes}

The oocyte collected from slaughterhouse either by aspiration or slicing were examined under inverted microscope and graded according to Wani et al. (9) as good (grade A), fair (grade B) and poor (grade C) (Figure 1, 2 and 3). On the basis of cumulus cells and uniform cytoplasm. Good: oocytes with many complete layers of cumulus cells and uniform cytoplasm. Fair: oocytes with thin or incomplete layers of cumulus cells and uniform cytoplasm. Poor: oocytes with few or no cumulus cells with fragmented cytoplasm.

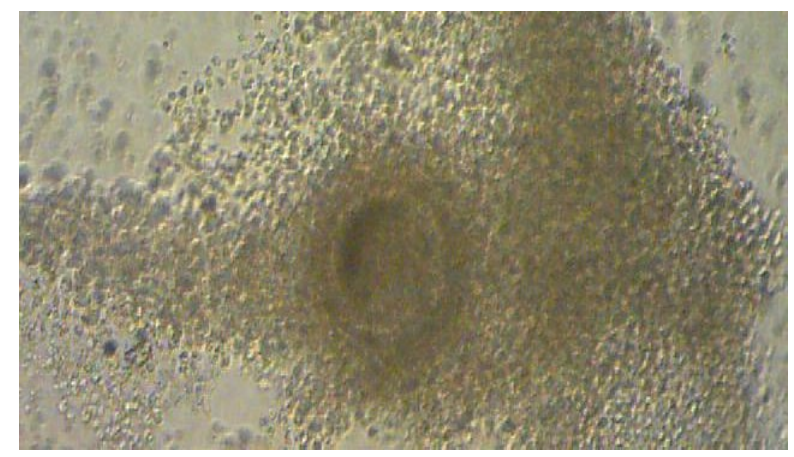

Figure 1: Grade A oocyte: Oocyte surrounded by several layers of cumulus cells $\times 40$.

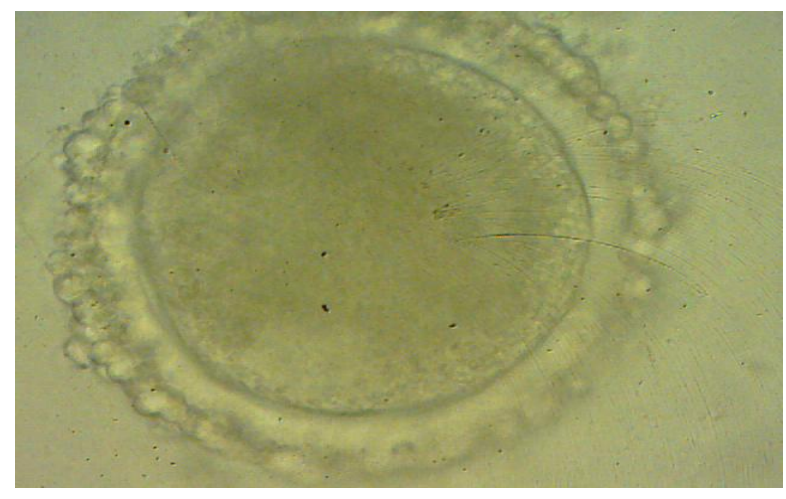

Figure 2: Grade B oocyte: Oocytes with thin or incomplete with thin layers of cumulus cells and uniform cytoplasm $\times$ 40. 


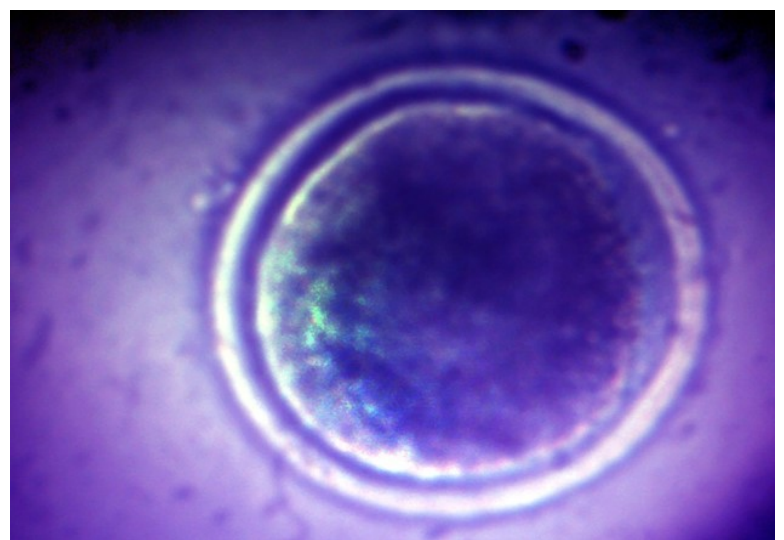

Figure 3: Grade C oocyte: Oocytes with few or no cumulus cells with fragmented oocyte $\times 40$.

\section{In Vitro maturation}

Only good and fair quality oocytes were selected (Figure 4).

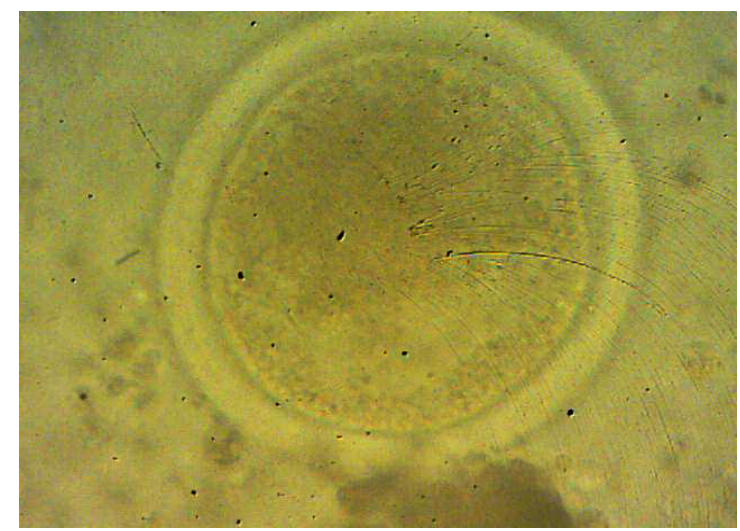

Figure 4: Showed matured oocyte with the first polar body $\times 40$.

\section{Tissue culture media}

Minimum Essential Medium (MEM) (with Lglutamine): Eleven $\mathrm{gm}$ of media was dissolved in approximately $600 \mathrm{ml}$ of double distilled water (DDW) and then the following component were added: Sodium bicarbonate powder (2.2 gm), HEPES buffer (Gibco, U.S.A.), (IM) $10 \mathrm{ml}$, Benzyl penicillin $100100 \mathrm{IU} / \mathrm{Ml}$, Streptomycin $10 \mathrm{mg} / \mathrm{ml}$, Fetal Calf Serum (F.B.S) $100 \mathrm{ml} / \mathrm{L}$ $10 \%$. The final volume of the media was completed to one liter with DDW and finally the medium was sterilized by using Nalgen filter $0.22 \mu \mathrm{m}$ filter unit.

Modified Tyrodes Albumin Lactate Pyruvate Media (mTALP): Filtered with 0.22 milipor Nalgen filter, stored at $-18{ }^{\circ} \mathrm{C}$ for one week (Table 1 ).
Table 1: Components of modified tyrodes albumin lactate pyruvate media

\begin{tabular}{lc}
\hline Components & Concentrations (mM) \\
\hline $\mathrm{NaCl}$ & 163.9 \\
$\mathrm{KCl}$ & 2.62 \\
$\mathrm{MgCl}_{2} .6 \mathrm{H}_{2} \mathrm{O}$ & 1.05 \\
$\mathrm{NaHCO}_{3}$ & 12.1 \\
$\mathrm{CaCl}_{2}$ & 2.0 \\
$\mathrm{Glucose}_{\text {Sodium Pyruvate }}$ & 4.5 \\
Sodium Lactate & 1.0 \\
$\mathrm{BSA}$ & 1.0 \\
$\mathrm{FCS}$ & $6 \%$ \\
$\mathrm{HCG}$ & $10 \%$ \\
eCG & 6.66 i.u./ $\mathrm{ml}$ \\
E & 13.4 i.u./ml \\
Streptomycin & $1 \mu \mathrm{g} / \mathrm{ml}$ \\
$\mathrm{Crystalline} \mathrm{penicillin}$ & $50 \mathrm{mg} / \mathrm{ml}$ \\
pH & 100 i.u./ ml \\
\hline
\end{tabular}

Tissue Culture Medium - 199 (Table 2). TCM-199 with Earle's salts and L-glutamine (Gibco, U.S.A.). All the substances were added to the TCM-199 according to the amount required. The cultured media were sterilized with Nalgen filter $0.22 \mu \mathrm{m}$ millipore and stored at $4{ }^{\circ} \mathrm{C}$ and used within one week after preparation. Estrus Goat Serum (EGS): Heat inactivated serum in $56^{\circ} \mathrm{C}$ for 30 minutes. The media were sterilized with nalgen filter ( 0.22 millipore filter: manufactured by Nalgennunc, U.S.A). The oocytes and fertilized ova and their development examined with inverted microscope with camera attached with computer manufactured by Olympus, Japan. The oocytes were washed twice in maturation media either TCM-199 or MEM or TALP. They were incubated in appropriate maturation medium at $39{ }^{\circ} \mathrm{C}$ temp. $5 \% \mathrm{CO}_{2}$ and $90 \%$ relative humidity for $27 \mathrm{hrs}$. The incubated petri dish was examined under inverted microscope. The presence of the first polar body was a good criteria for maturation of oocytes in vitro (IVM) (11) The numbers of matured oocytes were calculated.

\section{Semen collection and preparation}

Fresh semen was collected from two Bucks of proven fertility, presented in the farm of College of Veterinary Medicine, University of Fallujah, Fallujah, Al-Anbar province, by electro-ejaculator, and transported within 5 minutes to the Theriogenology lab. At $30-35{ }^{\circ} \mathrm{C}$. Semen samples were examined under light microscope to evaluate semen quality. The mass and individual motility was assessed. Samples showed less than $60 \%$ progressive motility were rejected. Ejaculates from two Bucks were pooled in equal quantities for final volume of $1 \mathrm{ml}$, in order to minimize the variation between bucks. The semen 
samples were warmed in a water bath at $35^{\circ} \mathrm{C}$. Dilution of the semen samples 1:10 with TALP or MEM or TCM-199 solutions. This suspension was diluted 1:1 with heparin containing media $(100 \mu \mathrm{g} / \mathrm{ml}$ Heparin salt) and then incubated for 45 minutes at $38^{\circ} \mathrm{C}$ according to the procedure described by Palamo et al. (12).

Table 2: Components of tissue culture medium - 199

\begin{tabular}{lc}
\hline Components & Concentrations \\
\hline $\mathrm{TCM}^{-199}$ & $0.950 \mathrm{gm} 90 \%$ \\
$\mathrm{NaHCo}_{3}$ & $2.2 \mathrm{gm}$ \\
Fetal Calf Serum & $10 \%$ \\
Na-pyruvate & $11.525 \mathrm{mg} / 100 \mathrm{ml}$ \\
$\mathrm{eCG}$ & $2.5 \mu \mathrm{g} / \mathrm{mL}$ \\
$\mathrm{E}_{2}-17 \beta$ & $1 \mu \mathrm{g} / \mathrm{ml}$ \\
Pencillin & $100 \mathrm{i.u} . / \mathrm{ml}$ \\
Streptomycin & $100 \mu \mathrm{g} / \mathrm{ml}$ \\
pH & 7.4 \\
m Osmol & 290 \\
\hline
\end{tabular}

\section{In vitro fertilization}

Capacitated sperms suspension was diluted to yield a concentration of $1.0 \times 10^{6} \mathrm{sperm} / \mathrm{ml}$ in fertilization medium (m MEM, m TCM-199 and Fert. TALP) with $\mathrm{pH}$ adjusted between 7.4-7.8. Only matured oocytes were kept in groups of 5-10 oocytes in one well out of 24 wells petri dish containing fertilization medium with spermatozoa incubated at $39{ }^{\circ} \mathrm{C}, 5 \% \mathrm{CO}_{2}, 90 \%$ relative humidity for 27 hours (5).

\section{Evaluation of oocytes}

At $24 \mathrm{hrs}$ after insemination, oocytes were evaluated as fertilized oocytes having $2^{\text {nd }}$ polar body or oocyte with sperm head in the cytoplasm. The numbers of fertilized oocytes were counted.

\section{In vitro culture}

Culture of previously fertilized oocytes (zygotes) (Figure 5,6 and 7) were performed. Embryo were cultured in different cultural media (MEM, TCM-199 and TALP) and incubated at $38.5-39^{\circ} \mathrm{C}, 5 \% \mathrm{CO}_{2}$ and $90 \%$ humidity. Embryonic development was observed every $24 \mathrm{hrs}$ and $50 \%$ of culture volume was replaced with fresh medium at $24 \mathrm{hrs}$ intervals. According to Keskintepe et al. (13) procedure, ova that did not show the next cleavage ago, were removed from the wells containing developing embryos at the time of each change of medium. Proportion of fertilized oocytes reached 2 to 4 cells stag (Figure 8 and 9) were recorded at $48 \mathrm{hrs}$ morula were observed at $120 \mathrm{hrs}$, blastocyst at $148 \mathrm{hrs}$ and expanded blastocysts at $216 \mathrm{hrs}$ after fertilization.

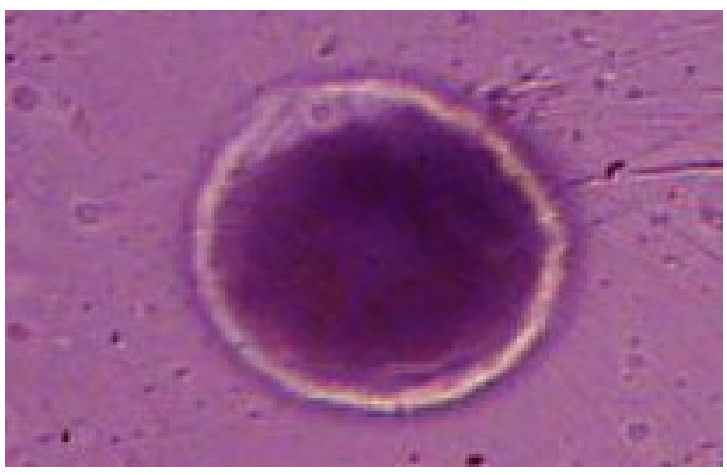

Figure 5: Fertilized oocyte showed the 2nd polar body $\times 40$.

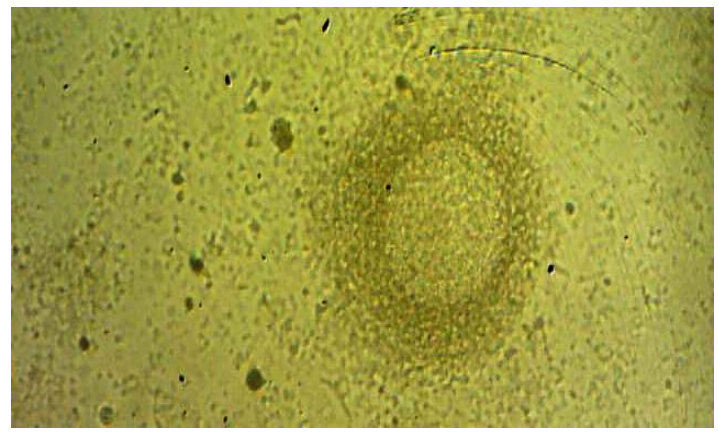

Figure 6: Fertilized oocyte with 2 nd polar body $\times 40$.

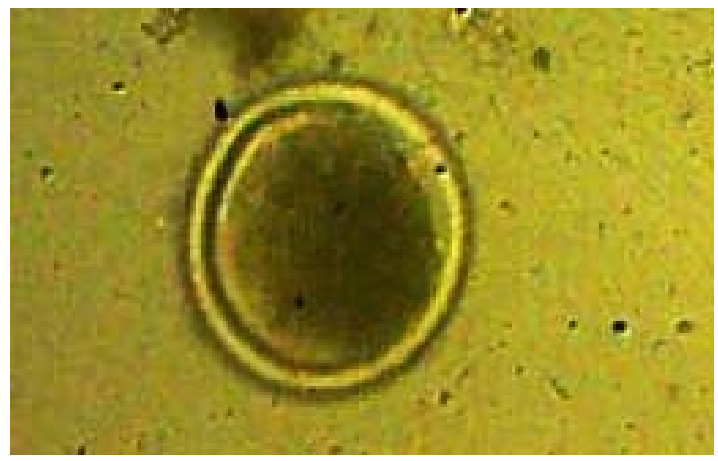

Figure 7: Fertilized oocyte showed expansion of cumulus cells $\times 10$.

\section{Evaluation of morulae and blastocysts}

Morphological evaluation of morulae and blastocysts were done according to Koeman et al. (14). Ova appearing (Figure 10) as a compacted mass of cells ( $\geq 16$ ) cells (Figure 11) 0 at $40 \mathrm{x}$ magnification under inverted microscope were classified as morulae. Embryo exhibiting presence of a blastocoel were classified as blastocysts (Figure 12 and 13). Embryo containing a blastocoel either emerging from zona pellucida or lacking a zona pellucida were classified as hatched blastocysts (Figure 14). 


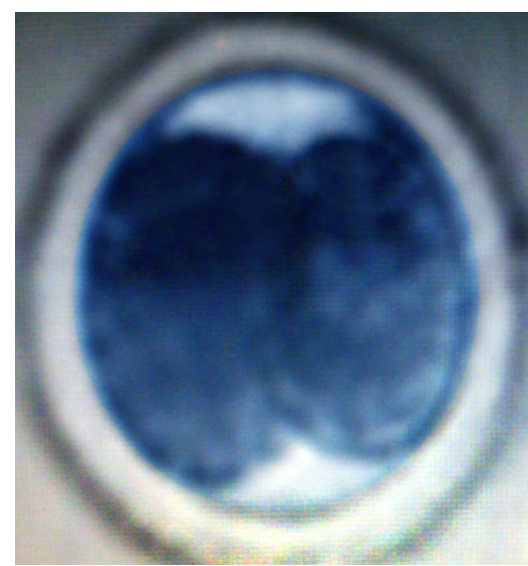

Figure 8: 2- cells embryo $\times 40$.

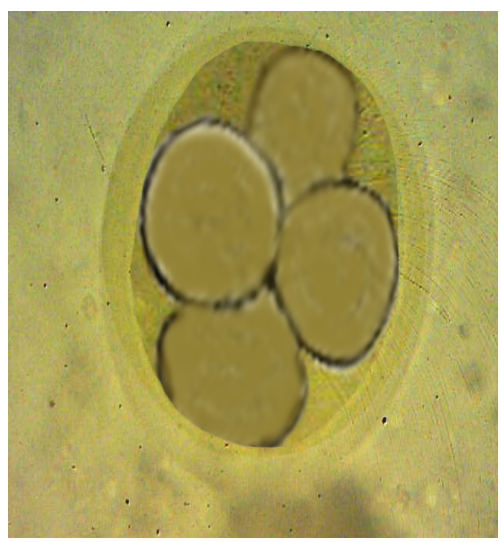

Figure 9: 4- cells embryo $\times 40$.

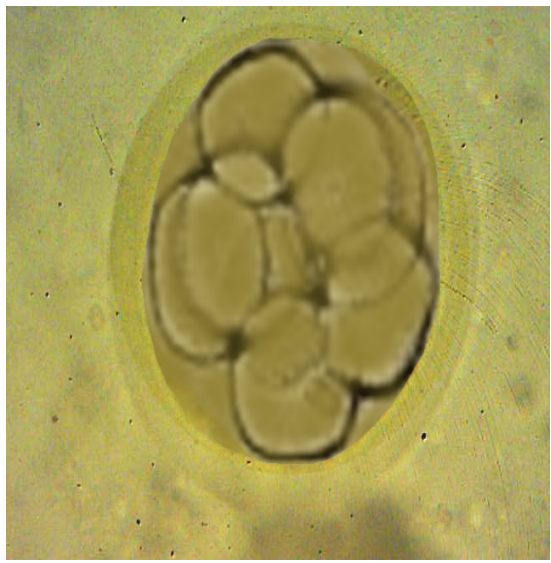

Figure 10: 8- cells embryo $\times 40$

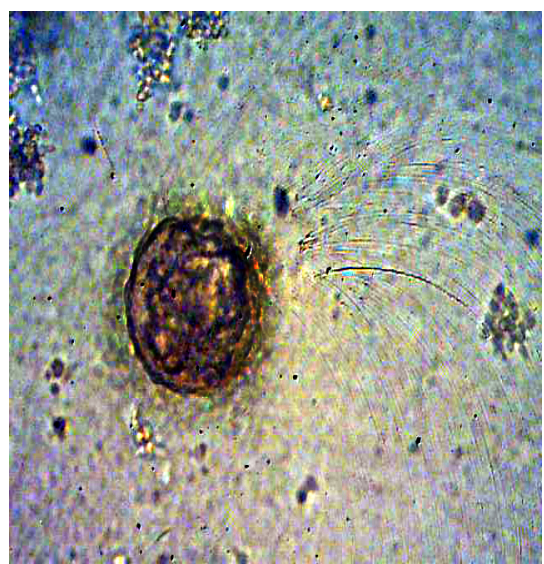

Figure 11: 16- cells embryo $\times 10$

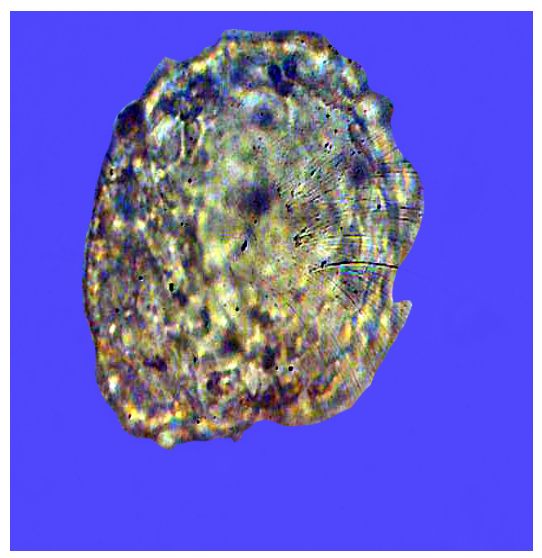

Figure 12: 8- days blastocyst $\times 40$.

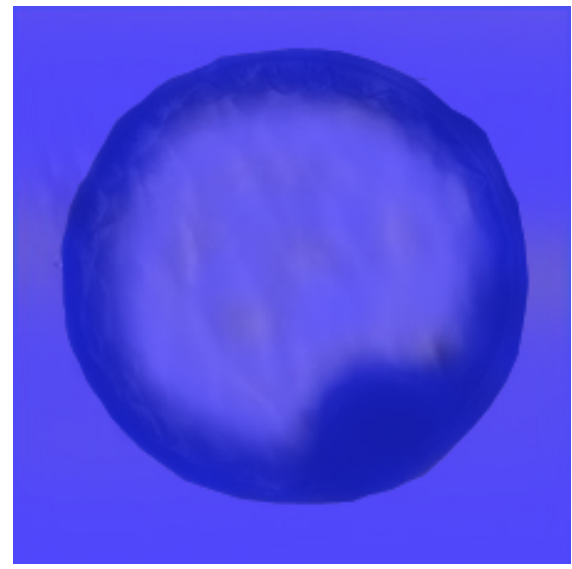

Figure 13: 8- days blastocyst. 


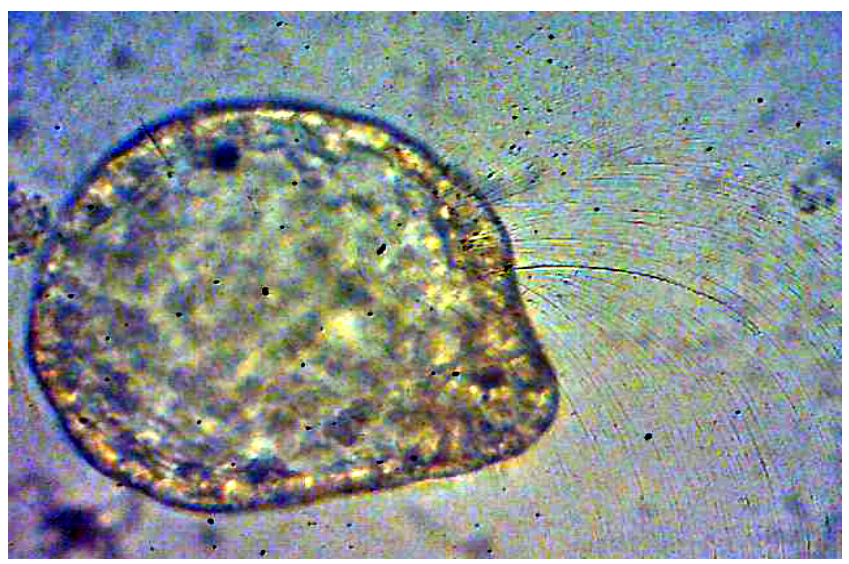

Figure 14: 9 days culture Hatched blastocyst $\times 40$.

\section{Staining}

All oocytes and stages cleavage of embryo, zygotes and blastocyst fixed with methanol-acetic acid (15) and stained with 5\% Giemsa for 8-10 minutes (16).

\section{Statistical analysis}

Student t-test and chi-square test were used for analysis of data according to Schefler (17).

\section{Results}

Table 3 showed the effect of season on oocyte recovery and maturation rate. It has been revealed that high recovery rate $87.3 \%(1135 / 1299)$ and maturation rate $45.6 \%$ (456/998) were observed at breeding season as compared with recovery rate of $72.5 \%(1150 / 1586)$ and maturation rate of $35.2 \%(269 / 808)$ respectively in non-breeding season. There was a significant difference at $\mathrm{P}<0.05$ in recovery rate and maturation rate between different season.

Table 4 showed the effect of season on fertilization rate $\%$ in black Iraqi goats. It had been found that fertilization rate was $60.05 \%(276 / 456)$ in breeding season, while it was $33.9 \%(145 / 269)$ in non-breeding season. There was a significant difference in fertilization rate at $\mathrm{P}<0.05$ between breeding and non-breeding season.

Table 5 showed the effect of breeding season on blastocyst production. The proportion of blastocyst obtained during breeding season was 56.41\% (154/273), while it was $43.24 \%(45 / 148)$ in non-breeding season. There was a significant difference at $\mathrm{P}<0.05$ between different season.

Table 3: Effect of breeding season on recovery rate and maturation rate in black Iraqi local goats

\begin{tabular}{lcccccc}
\hline Season & No. of ovary & No. of follicle Oocyte recovery & Maturation rate & No. of mature oocyte & Maturation rate \\
\hline Breeding season & 360 & 1299 & $1135(87.3 \%)^{\mathrm{a}}$ & 998 & 456 & $45.69 \%$ \\
Non-breeding season & 838 & 1586 & $1150(72.5 \%)^{\mathrm{b}}$ & 808 & 269 & $33.29 \%{ }^{\mathrm{b}}$ \\
\hline
\end{tabular}

Mean values in the same column with different superscripts differ significantly at $\mathrm{P}<0.05$.

Table 4: Effect of season on fertilization rate in black Iraqi goats

\begin{tabular}{lccc}
\hline \multirow{2}{*}{ Season } & $\begin{array}{c}\text { No. of cultured } \\
\text { matured oocytes }\end{array}$ & $\begin{array}{c}\text { No. of fertile Fertilization } \\
\text { oocytes }\end{array}$ & rate $\%$ \\
\hline Breeding & 456 & 276 & $60.05 \%$ \\
Non-breeding & 269 & 145 & $53.9 \%$ \\
\hline
\end{tabular}

Mean values in the same column with different superscripts differ significantly at $\mathrm{P}<0.05$.

Table 5: Effect of season on the blastocyst production rate in black Iraqi local goats

\begin{tabular}{lccc}
\hline Season & $\begin{array}{c}\text { No. of cultured } \\
\text { matured zygote }\end{array}$ & $\begin{array}{c}\text { No. of } \\
\text { fertilized } \\
\text { oocyte }\end{array}$ & $\begin{array}{c}\text { Blastocyst } \\
\text { production } \\
\text { rate }\end{array}$ \\
\hline Breeding & 273 & 154 & $56.41 \% \mathrm{a}$ \\
Non-breeding & 148 & 64 & $43.24 \% \mathrm{~b}$ \\
\hline
\end{tabular}

Mean values in the same column with different superscripts differ significantly at $\mathrm{P}<0.05$.

\section{Discussion}

The results revealed that recovery rate $87.3 \%$ $(1135 / 1299)$ and maturation rate $45.6 \%$ (456/998) were observed at breeding season compared with recovery of $72.5 \%(1150 / 1586)$ and maturation rate of $35.2 \%(269 / 808)$ respectively in non-breeding season.

Similar observations had been reported by several investigators $(11,14,18,19)$. It has been reported by Ramsingh et al. (20) that ovarian diameters play an important role on oocyte grading and recovery rate in goat.

The ovarian size variation is associated with breed, season and nutritional status (20). It has been reported that differences exist in the onset and length of breeding season among the various breeds od goats, and even between individual animals within breed, geographic location, particularly degree of latitude, has a significant impact on timing and length of breeding season (1).

The results also showed that fertilization rate was $60.05 \%(276 / 456)$ in breeding season, while it was $53.9 \%$ $(145 / 269)$ in non-breeding season. Similar observation has 
been reported by Camarago et al. (2) and Kharchi et al. (5). These results might be attributed to the effect of heat stress on oocyte quality could lead to seasonal variation in the success rate of.

In vitro embryo production system (12). The results disagreed with the finding of Rao et al. (3) in sheep, who reported that were no differences in IVF during breeding and non-breeding season. Also, it has been observed that the number and quality of oocytes obtained does not support differential folliculogenic activity of the ovaries during the breeding and non-breeding season. It has however possible that while ovarian follicular growth not differ among season, the amount of estrogen produced by ovarian follicles may differ between the season resulting in observed differences $(3,4)$. So, estimation of estrogen content of ovarian follicles during breeding and nonbreeding season could clarify seasonal effect on IVF. Alteration, antral follicles that appear on the ovaries during the non-breeding season may not grow to ovulatory size to produce sufficient estrogen. It was also suggested that the ability of oocytes to undergo IVM as assessed by extrusion of the first polar and their development did not differ significantly between the seasons but might depend on the medium (3).

The results showed that the proportion of blastocyst obtained during breeding season was 56.4\% (154/274), while it was $43.24 \%(46 / 148)$ in non-breeding season. These results are disagreed with Rao et al. (3) who was reported that there was no difference in blastocyst production in different season. Our results suggested that during breeding season good quality oocytes recovered from large follicle produce or rate of blastocyst. The disagreement or variation in the results obtained might be attributed to breeding and environmental difference. It was concluded that there was an effect of season on in vitro production of embryo in Iraqi local black goats.

\section{References}

1. Zarazaga LA, Guzman JL, Domminguez C, Perez MC, Prieto R. Effect of plane of nutrition on seasonality of reproduction in Spanish Payoya goats. Anim Reprod Sci. 2004;87:253-267.

2. Camargo LSA, Viana JHM, Sa WF, Ferreria AM, Ramos AA, Vale VR. Factors influencing in vitro embryo production. Anim Reprod. 2006;3:19-28.
3. Rao BS, Naidu KS, Amarnath D, Vagdevi R, Rao AS, Brahmaiah K, Rao VH. In vitro maturation of sheep oocytes in different media during breeding and non-breeding season. Small Rum Res. 2002;43:31-36.

4. Kaushish SK. Sheep production in tropic and subtropics. $1^{\text {st }}$ ed. India: Scientific Publisher; 1994. p. 26-28.

5. Khareche SD, Goel P, Jha BK, Goel AK, Jindal SK. Factors influencing in vitro embryo production efficiency caprine oocytes: A review. Indian J Anim Sci. 2011;81(4):344-361.

6. Catala MG, Hammami S, Roura M, Izquierdo D, Cavlni S, Paramio MT. Effect of years season on IVF of prepubertal goats using fresh semen. $29^{\text {th }}$ Annual Meeting, Istanbul: Turkey; 2013.

7. Mardenli O, Aryan H, Almeziad M, Bogdan L. Effects of month of the year on in vitro embryo production of Syrian Awassi sheep. Inter Educ Applied Sci Res J. 2017;2(12):10-12.

8. Al-Kass JE, Al-Jalili ZF, Aziz DE. Sheep and goat; principles of reproduction and breeding. University of Baghdad, Collage of Agriculture. 1993.

9. Wani NA, Wani GM, Khan MZ, Salahudin S. Effect of oocytes harvesting technique on in vitro maturation and in vitro fertilization in sheep. Small Rum Res. 2000;36:63-67.

10. Wani NA. In vitro maturation and in vitro fertilization of sheep oocytes. A review. Small Rum Res. 2002;44:89-95.

11. Farin CE, Haslar JF, Martus NS, Stokes JE. A comparison of Menezos B2 and tissue culture medium-199 for IP bovine blastocysts. Theriogenol. 1997;48:699-709.

12. Palamo MJ, Izquierdo D, Mogas T, Paramio MT. Effect of semen preparation on IVF of prepubertal goat oocytes. Theriogenol. 1999;50:927-940.

13. Keskintepe L, Simplicio A, Brackett BG. Caprine blastocyst development after in vitro fertilization with spermatozoa frozen in different extenders. Theriogenol. 1998;49:1265-1274.

14. Koeman JK, Keefer CL, Baldassare H, Lane M, Gardner DK, Doweny BR. Developmental competence of prepubertal and adult goat oocytes cultured in semi-defined media. Theriogenol. 2000;53:597.

15. Pineda MH, Dooley MP. McDonalds veterinary endocrinology and reproduction. $5^{\text {th }}$ ed. Iowa: Iowa State Press; 2003.

16. Davachi ND, Shahneh AZ, Kohram H, Zhandi M, Dashti S, Shamsi $\mathrm{H}$, Moghadam R. In vitro ovine embryo production: the study of seasonal and oocyte recovery method effects. Iran Red Cr Med J. 2014;16:(9):1-6

17. Schefler WC. Statistics of biological sciences. $4^{\text {th }}$ ed. Addison Wesley Publication; 2000.

18. Hoque SAM, Kabiraj SK, Khandoker MY, Mondal A, Tareq K. Effect of collection techniques on cumulus oocyte complex (COCs) recovery, in vitro maturation and fertilization of goat oocytes. African J Biotech. 2011;10(45):9177-9181.

19. King W, Gustavsson I, Bane A. A method for preparation of chromosomes from bovine zygotes and blastocyst. Vet Sci Commun. 1979;3:51-56.

20. Ramsingh L, Sadosivarao K. Muralimo ovarian biometrics and oocyte granding percentage of yield in local goats of Andhra Pradesh. IOSR J Pharmacy. 2013;3(1):47-49. 